\title{
Diversity of Vegetation Dominated by Selected Grass Species on Coal-Mine Spoil Heaps in Terms of Reclamation of Post-Industrial Areas
}

\author{
Agnieszka Błońska', Agnieszka Kompała-Bąba ${ }^{1 *}$, Edyta Sierka ${ }^{1}$, Wojciech Bierza', \\ Franco Magurno', Lynn Besenyei², Karolina Ryś' ', Gabriela Woźniak' \\ 1 Department of Botany and Nature Protection, Faculty of Biology and Environmental Protection, University of \\ Silesia in Katowice, Jagiellońska 28, 40-032 Katowice, Poland \\ ${ }^{2}$ Faculty of Science and Engineering, University of Wolverhampton, Wulfruna Street Wolverhampton WV1 1LY, \\ United Kingdom \\ * Corresponding author's e-mail: agnieszka.kompala-baba@us.edu.pl
}

\begin{abstract}
S
Grasses have a considerable potential for the adaptation to various, often extreme, habitat conditions. The aim of the work was to present the vegetation diversity of the coal-mine spoil heaps with the dominant share of grasses and to identify the main factors responsible for this diversity in the aspect of post-industrial land reclamation. The communities differ in reference to the species preferences to light, moisture, soil fertility and reaction, which is reflected in the wide variety of microhabitats in the area. It was shown that the increase in the abundance of certain grass species, including Calamagrostis epigejos, Festuca rubra, Festuca arundinacea, Phragmites australis, has a significant negative impact on the species richness, species diversity and the uniformity of distribution of species of the plant community. Preliminary analyses revealed that on post-mining waste, the biomass production of the dominant species is negatively correlated with biodiversity. The knowledge about the biology and ecology of grass species, as well as on the assembly rules may be used in the reclamation of degraded areas. Gaining the knowledge about the vegetation diversity of the coal-mine spoil heaps with the dominant share of grasses can be useful in planning the reclamation works, taking into account natural processes, which leads to the creation of a permanent vegetation cover at a given site, protecting it against water or wind erosion. In the future these areas may provide a number of important ecosystem services.
\end{abstract}

Keywords: grass species, dominants, diversity, biomass, coal-mine spoil heaps, plant community, reclamation

\section{INTRODUCTION}

Coal mine spoil heaps that were formed as a result of long lasting mining activity are an inseparable element of the Upper Silesian landscape. These sites are very specific habitats, often without soil and vegetation cover that is linked to the absence of a soil seed bank and lack or low amount of nutrients in the substratum. In addition, they can be characterized by high temperature, salinity, significant fluctuations in moisture, and thermal activity. Instability of the coarse grain substrate causes its susceptibility to the water or mass erosion [Maciak, 1999; Bradshaw, 2000; Woźniak, 2010; Chmura et al.,
2011; Chmura et al., 2013; Molenda et al., 2013; Markowicz et al. 2015]. All these factors contribute to the difficulty of colonizing them both by plant and animal species. However, the results of many studies revealed [Rostański and Woźniak, 2007; Woźniak, 2010; Błońska et al., 2013; Nicia et al., 2014], that there are species which colonize this area during spontaneous succession and form plant communities and are frequently different from those recorded on other anthropogenic sites. The vegetation patches that occur on coal mine spoil heaps are frequently dominated by single species that are characterized by high frequency and abundance, giving them a specific physiognomy. The dominant species have 
a set of functional traits [e.g. height, high seed production, parameters of leaves, biomass, root traits] that help them successfully compete with accompanying species and reduce their abundance in patches [Frieswyk et al. 2007; Ryś et al.,2016]. Therefore, they play a crucial role in shaping both the abiotic [soil formation, nutrient and water cycling] and biotic components of plant communities [Simberloff and Von Holle, 1999]. In reference to such species, a ,mass ratio hypothesis [MRH]" was formulated that explains the influence of some species on ecosystem processes or services. According to Grime [1998] the influence of dominant plants is proportional to their abundance in a given community. The MRH hypothesis was also confirmed during the experimental studies conducted by Díaz et al. [2007] or Mokany et al. [2008] who stated that the functioning of ecosystem is determined by the morphological, physiological or phonological traits of species that significantly contribute to the production of a biomass.

Grass species play an important role in colonization of such harsh areas [Kompała, Woźniak 2001; Rostański and Woźniak, 2007; Ryś et al., 2016], because they can adapt to various, often extreme, environmental conditions that occur on a post-industrial sites. They frequently possess wide ecological amplitude [Kozłowski et al. 2000]. The ability to reproduce vegetatively and to lateral spread via rhizomes as well as dis- persal by wind, enables them to spread into new sites and occupy them [Frey 2000; Rostański, Woźniak, 2007]. They frequently play a pioneer role, influencing the soil formation and its physical and chemical properties. Since most of them have a well-developed root system, they also protect the soil against water and wind erosion. Therefore, they are very useful in the reclamation practice. [Frey, 2000; Woźniak, 2010]

The aim of the study is [i] to present the differentiation of spontaneous vegetation dominated by chosen grass species occurring on the coalmine spoil heaps; [ii] to identify the main factors responsible for this diversity in the aspect of postindustrial land reclamation; [iii] to find the relations between cover of a dominants and chosen diversity indices and plant biomass.

\section{MATERIALS AND METHODS}

\section{Site description}

The study area is situated in the central part of the Silesian Upland in the mesoregion of the Katowice Upland [Kondracki, 2002]. The following coal-mine spoil heaps were selected for detailed studies (Fig. 1.) [Hałda „Sośnica”, Hałda „Wesoła”, Hałda «Maria», Hałda «Kostuchna»]. They were formed during 1900-1995 as a result of intensive exploitation

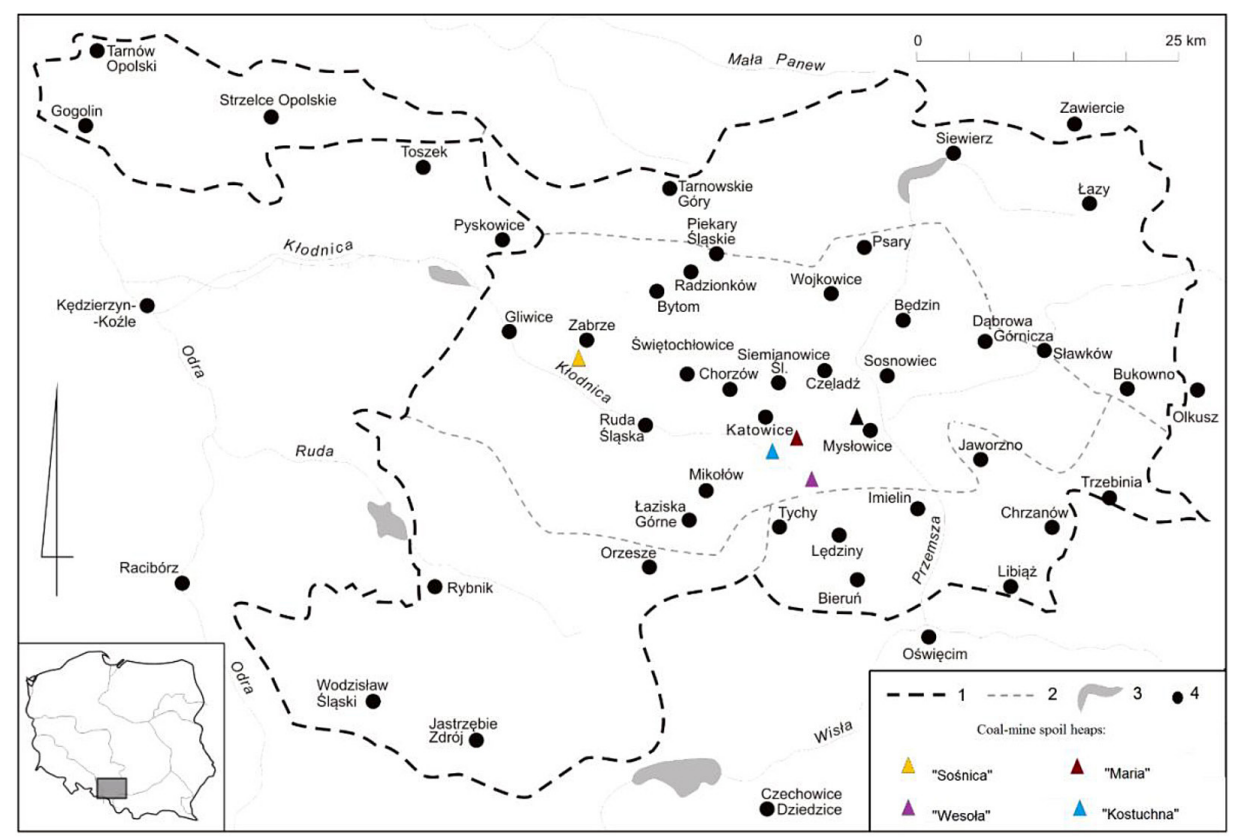

Fig. 1. Location of coal mine spoil heaps [marked in colour] in the study area [Woźniak, 2010, changed] Explanations: 1 - Area of the Silesian Upland macroregion, 2 - Katowice Upland mesoregion, 3 - water reservoirs, 4 - cities 
of hard coal by such coal mines as: KWK „SośnicaMakoszowy”, KWK „Mysłowice Wesoła”, KWK „Murcki” (KWK „Murcki-Staszic”- Ruch „Boże Dary") [Mitek, 2015; Pełka-Gościniak, 2015]. The spoil material consists mainly of waste rock and other industrial wastes from mining excavations. Some reclamation works were undertaken, mainly involving afforestation [Mitek, 2015; Gajos et al, 2010; Pełka-Gościniak, 2015]. The technical reclamation work enabled to shape the slopes resulting in embankments construction of super-level and convex dome shape, often irregular slopes and a flat top, with an average height of $>30 \mathrm{~m}$. Most parts of the heap are covered with non-forest vegetation. The dumping grounds are used for tourist purposes, i.e. for cycling and motor sports, as well as by hikers [Probierz et al. 2017].

\section{METHODS}

In the experiment, 70 sample plots were established in patches dominated by the chosen grass species. They have a shape of a circle with a radius of $3 \mathrm{~m}$. In each sample plot, the species composition was noted together with the abundance of species evaluated on a 10-degree scale $(<1 \%, 1-5 \%, 5-10 \%$, and then every $10 \%)$. Moreover, smaller plots with a side of $0.5 \mathrm{~m}$ were established on 70 sample plots, from which the surface parts of plants (biomass) were collected: separately for a dominant and the rest of species (accompanying species). Shortly after collecting, the fresh mass of species was immediately weighed using a field weight. The samples were then dried at $105^{\circ} \mathrm{C}$ in an incubator for 24 hours in the air and weighted again (weight of dry biomass was obtained) as a result of which the weight of dry biomass was obtained (dried at $105^{\circ} \mathrm{C}$ ).

On the basis of the classification results, a synoptic table was prepared. The diagnostic species were determined using as a measure of fidelity phi coefficient of association. The species were classified into ecological groups on the basis of Matuszkiewicz [2001] and Oberdorfer et al. [1990]. Species richness, Shannon-Wiener diversity index $\left(H^{\prime}\right)$, Simpson dominance index (D), Evenness index (E) were calculated in JUICE 7. 0.64 [Tichý, 2002] in order to show the relation between the abundance of a dominants and other characteristics of a community [Tichý, Holt, 2006]. In order to present the habitat preferences of the species that constitute the plant commu- nities, the average Ellenberg's indicators values (L, F, R, N) were calculated for each sample plot [Ellenberg et al. 1992] in JUICE 7 0. 64 [Tichý, 2002]. The groups of communities were compared using the non-parametric Kruskal-Wallis test [StatSoft, INC. 2011]. The names of species were adopted after Mirek et al. [2002].

\section{RESULTS}

The hierarchical classification of 70 sample plots enabled us to distinguish 5 groups (clusters) of communities dominated by grasses such as wood small-reed (Calamagrostis epigejos); flattened meadow-grass (Poa compressa); red fescue (Festuca rubra); tall fescue (Festuca arundinacea) and common reed (Phragmites australis) (Table 1) They contain from 8 to 17 plots. The number of species recorded in individual clusters ranges from 23 to 55 species. In individual communities, from 3 to 15 diagnostic species were recorded. High fidelity (phi $>50$ ) to the given community characterized such grass species as: Festuca rubra, Festuca arundinacea, Poa compressa or Phragmites australis.

\section{Taxonomic diversity}

The most diverse communities in reference to floristic composition were characterized by high abundance of such species as: flattened meadow grass Poa compressa $\left(H^{\prime}-1.89\right)$, wood small reed Calamagrostis epigejos $\left(H^{\prime}-1.42\right)$, tall fescue Festuca arundinacea $\left(H^{\prime}-1.45\right)$, whereas the communities with dominance of common reed Phragmites australis $\left(H^{\prime}-0.91\right)$ were less diverse. Phragmites australis has the highest average abundance (70\%) in patches (Fig. 2a). During studies, the patches with the lower abundance of $20 \%$ were rarely recorded. In comparison with other plant communities, the recorded values of Simpson's dominance index were the highest (Fig. 2d). In the patches with such dominants as Calamagrostis epigejos (1), Festuca rubra (3), Festuca arundinacea (4), the mean cover of dominants plant ranges from 30 to $60 \%$.

The values of Simpson dominance index range on average from 0.25 (Poa compressa com.), following 0.41 (in case of Calamagrostis epigejos, Festuca arundinacea), 0.53 (Festuca rubra com.) to 0.62 (Phragmites australis com.). Poa compres$s a$ has the average abundance in patches $30 \%$. The maximum abundance of this species reaches $40 \%$. 
Table 1. The characteristics of plant communities occurring on coal-mine spoil heaps of the Katowice Upland

\begin{tabular}{|c|c|c|c|c|}
\hline No & Diagnostic species: & Constant species: & Dominant species: & $\begin{array}{l}\text { Number } \\
\text { of grasses }\end{array}$ \\
\hline $\begin{array}{l}\mathrm{Ce} \\
(17)\end{array}$ & $\begin{array}{l}\text { Calamagrostis epigejos } 44.2 \text {, } \\
\text { Senecio viscosus } 31.0\end{array}$ & $\begin{array}{l}\text { Calamagrostis epigejos 100, Poa } \\
\text { compressa 53, } \\
\text { Solidago gigantea } 53\end{array}$ & $\begin{array}{l}\text { Calamagrostis epigejos } 88, \\
\text { Solidago gigantea } 6\end{array}$ & 6 \\
\hline $\begin{array}{l}\mathrm{Pc} \\
(17)\end{array}$ & $\begin{array}{l}\text { Achillea millefolium } 30.3 \text {, , Calamagrostis } \\
\text { epigejos } 32.4 \text {, Daucus carota } 36.2 \text {, } \\
\text { Echium vulgare } 41.0 \text {, Erigeron annuus } \\
\text { 55.9, Leontodon autumnalis } 38.3 \text {, Lotus } \\
\text { corniculatus } 38.0 \text {, Picris hieracioides } \\
\text { 50.6, Plantago lanceolata } 44.4 \text {, Poa } \\
\text { compressa 57.8, Rumex crispus } 38.3 \text {, } \\
\text { Taraxacum officinale } 48.7\end{array}$ & \begin{tabular}{|l|} 
Calamagrostis epigejos $\mathbf{8 8}$ \\
Daucus carota 82 , Erigeron \\
annuus 65, Hieracium piloselloides \\
59, Lotus corniculatus 65, \\
Medicago lupulina 65, Picris \\
hieracioides 88, Poa compressa \\
100, Solidago gigantea 53, \\
Taraxacum officinale 71
\end{tabular} & Poa compressa 71 & 10 \\
\hline $\begin{array}{c}\mathrm{Fr} \\
(15)\end{array}$ & \begin{tabular}{|l|} 
Festuca arundinacea 30.9, Festuca rubra \\
$\mathbf{5 9 . 7 ,}$ Vicia cracca 33.1, Vicia hirsuta 33.4, \\
\end{tabular} & \begin{tabular}{|l|}
$\begin{array}{l}\text { Festuca arundinacea } 67, \text { Festuca } \\
\text { rubra } 100\end{array}$ \\
\end{tabular} & $\begin{array}{l}\text { Festuca arundinacea } 7, \\
\text { Festuca rubra } 87\end{array}$ & 2 \\
\hline $\begin{array}{l}\text { Fa } \\
(8)\end{array}$ & 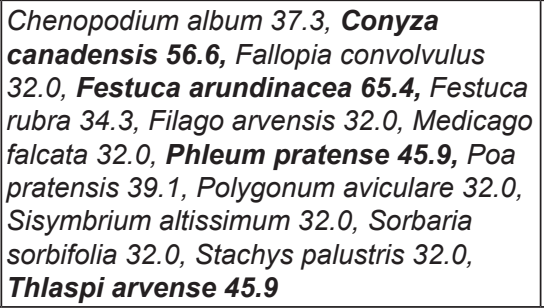 & $\begin{array}{l}\text { Conyza canadensis } 62, \text { Daucus } \\
\text { carota } 62 \text {, Festuca arundinacea } \\
100, \text { Festuca rubra } 75\end{array}$ & Festuca arundinacea 100 & 6 \\
\hline $\begin{array}{l}\text { Pha } \\
(13)\end{array}$ & $\begin{array}{l}\text { Agrostis gigantea } 35.6 \text {, Arrhenatherum } \\
\text { elatius } 35.6 \text {, Bidens frondosa } 35.6, \\
\text { Phragmites australis } 77.5 \text {, Poa palustris } \\
\text { 45.0, Urtica dioica } 35.6\end{array}$ & $\begin{array}{l}\text { Calamagrostis epigejos } 54, \\
\text { Phragmites australis } 100, \\
\text { Solidago gigantea } 62\end{array}$ & Phragmites australis 92 & 7 \\
\hline
\end{tabular}

Explanations: Ce - community Calamagrostis epigejos, Pc - community Poa compressa, Fr - community Festuca rubra, Fa -community Festuca arundinacea, Pha - community Phragmites australis

\section{Dominant species and their impact on species richness, species diversity, evenness, biomass}

No statistically significant correlation was found between the abundance of a dominant and the number of species (Table 2). The largest average number of species was recorded in the patches (Fig. 3) dominated by Poa compressa [average 13 species], followed by Festuca arundinacea (average 10 species) and Calamagrostis epigejos (average 10 species). In the remaining panels with the participation of both Festuca rubra and Phragmites australis as dominant species, the total number of species was slightly lower (mean of 6-8 species).

Statistically significant negative correlations were found between the cover of the majority of dominants and the values of Shannon-Wiener diversity index (H') and evenness (E). Only in the case of Poa compressa, there was no statistically significant correlation between the flattened meadow grass cover and the species diversity of the patches. The dominant cover, on the other hand, had a negative effect on the values of the evenness index.

Table 2. Spearman's rank correlation coefficient between cover of dominant species and selected variables (statistically significant results are highlighted in red; $p<0.05$ )

\begin{tabular}{|l|c|c|c|c|c|c|}
\hline \multicolumn{1}{|c|}{ Grass-dominated community } & 1 & 2 & 3 & \multicolumn{2}{c|}{4} & 5 \\
\hline Variable: & \multicolumn{5}{|c|}{ abundance of the dominant [\%] } \\
\hline - No. species richness & -0.03 & 0.46 & 0.24 & -0.71 & -0.55 \\
- Shannon-Wiener diversity index (H') & -0.72 & 0.04 & -0.57 & -0.91 & -0.80 \\
- Evenness index (E) & -0.89 & -0.72 & -0.68 & -0.91 & -0.80 \\
- Simpson's dominance index (D) & 0.84 & 0.26 & 0.65 & 0.91 & 0.78 \\
\hline Fresh biomass of a dominant (weight) & 0.81 & 0.73 & 0.54 & 0.17 & 0.76 \\
\hline Fresh biomass of accompanying species (weight) & -0.22 & 0.41 & -0.36 & -0.04 & 0.24 \\
\hline Dry biomass of a dominant (weight) & 0.86 & 0.50 & 0.07 & 0.43 & 0.58 \\
\hline Dry biomass of accompanying species (weight) & -0.16 & 0.33 & -0.52 & 0.16 & 0.14 \\
\hline
\end{tabular}

Explanations: 1 - Calamagrostis epigejos com., 2 - Poa compressa com., 3 - Festuca rubra com., 4 - Festuca arundinacea com., 5 - Phragmites australis com. 

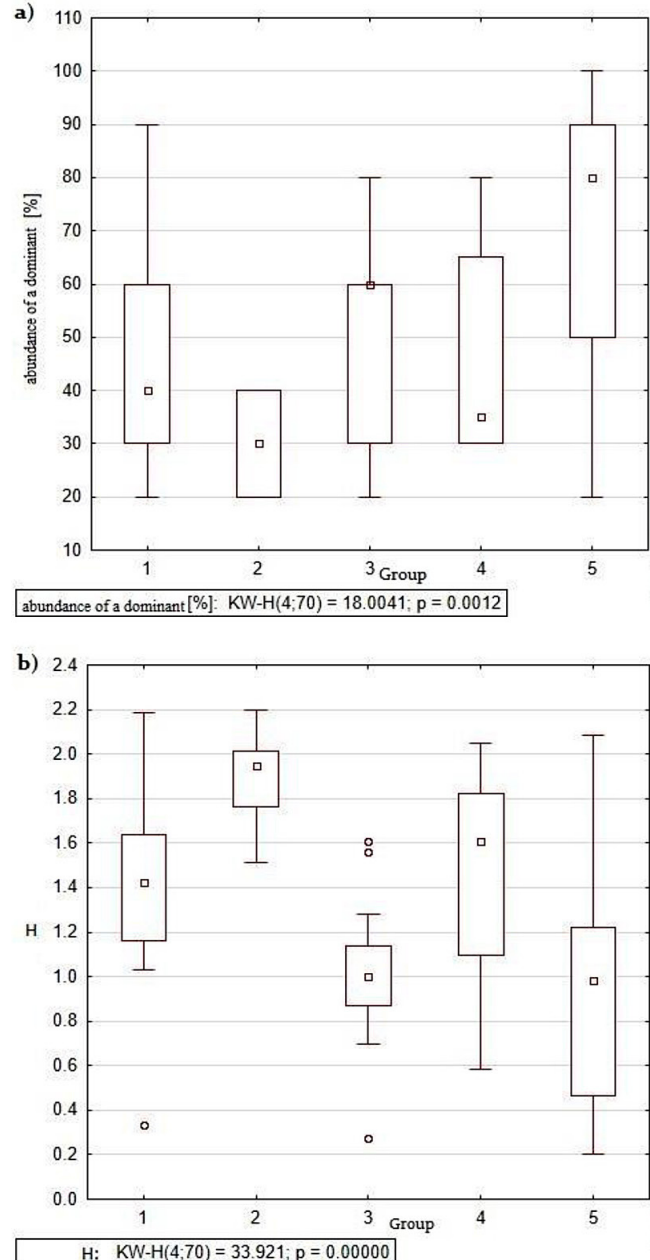
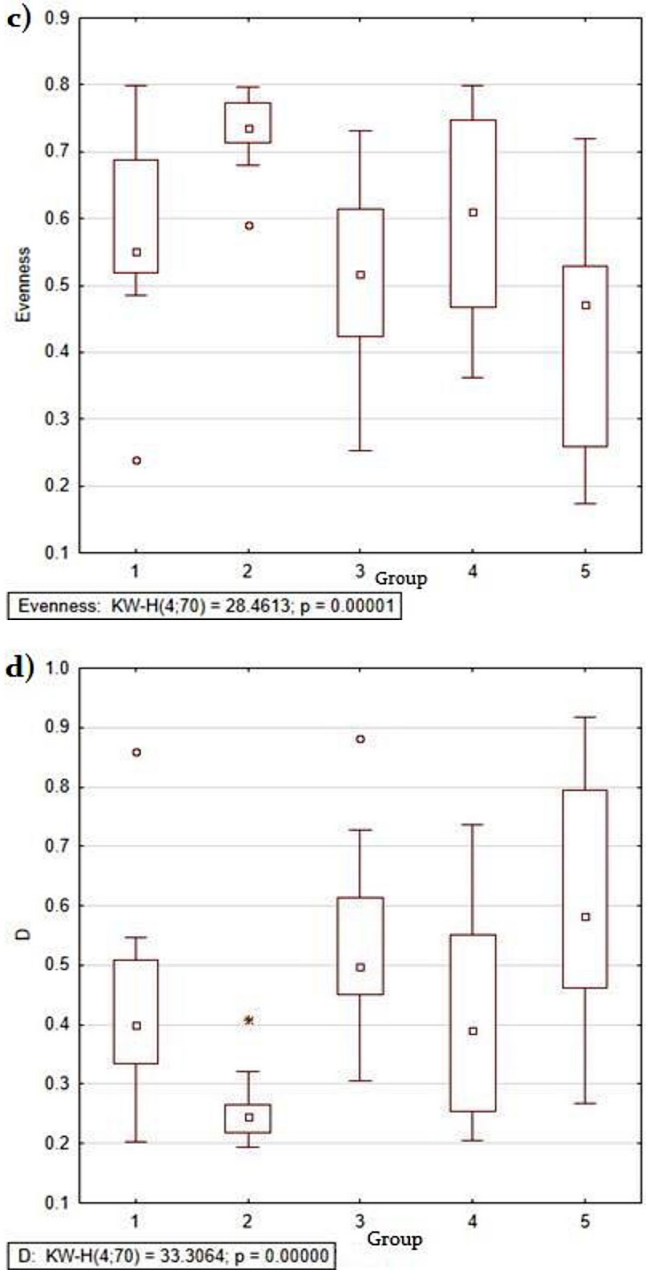

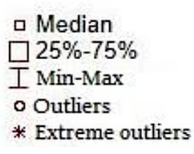

Fig. 2. The comparison of grass-dominated communities in reference to: a) abundance of a dominant; b) Shannon-Wiener diversity index (H'); c) Evenness (E); d) Simpson's dominance index (D). Abbreviations: 1 - Calamagrostis epigejos com., 2 - Poa compressa com., 3 -Festuca rubra com., 4 - Festuca arundinacea com., 5 - Phragmites australis com

The fresh biomass of dominant species was different in the patches of the most frequent vegetation types. The highest fresh biomass was found in the patches dominated by Phragmites australis and Calamagrostis epigejos, whereas the lowest in the patches dominated by Poa compressa (Fig. 4a). There were no statistically significant correlations between the fresh biomass of accompanying species and the dominant cover (Fig. 4b).

\section{Habitat preferences of species occurring in grass-dominated communities on the coal- mine spoil heaps}

While comparing the grass-dominated communities in terms of habitat preferences of species, it was shown that the communities of Phragmites australis are significantly different due to the habitat preferences of species in terms of humidity, higher nutrient content and attachment of species to shady places. The statistically significant differences were observed between the Phragmites australis community and the Poa compressa and Festuca rubra communities in relation to light (L) and moisture (F) (Fig. 5a, 5b).

The patches with Phragmites australis consist of the species thatpreferwetsoilsand shady places. In contrast, in the floristic composition of patches with Poa compressa and Festuca rubra, the species that are confined to dry soils and open places were found. The statistically significant differences were found in the floristic compo- 


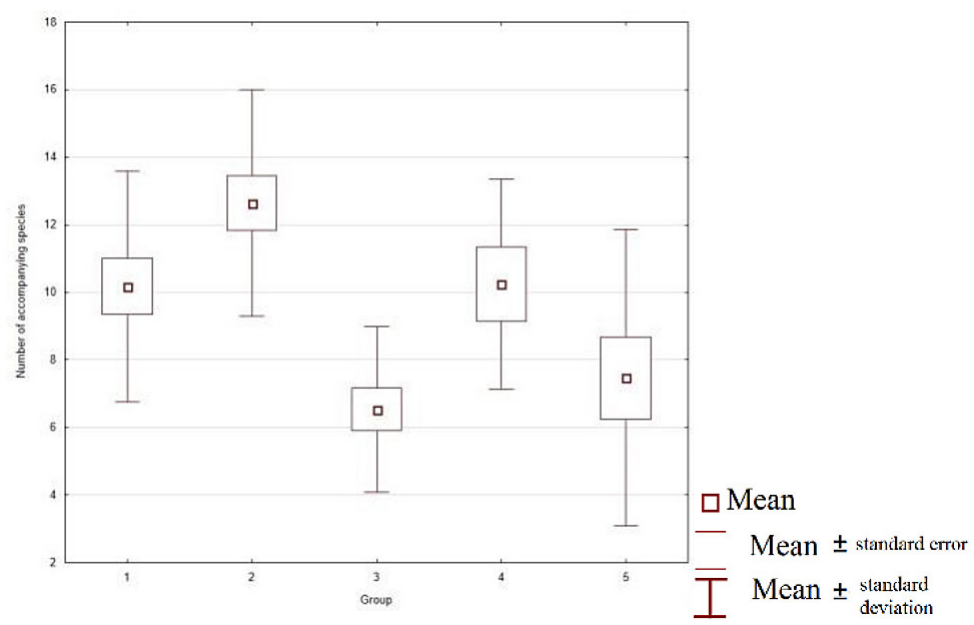

Fig. 3. The comparison of grass communities in reference to number of accompanying species Abbreviations: 1 - Calamagrostis epigejos com., 2 - Poa compressa com., 3 - Festuca rubra com., 4 - Festuca arundinacea com., 5 - Phragmites australis com.
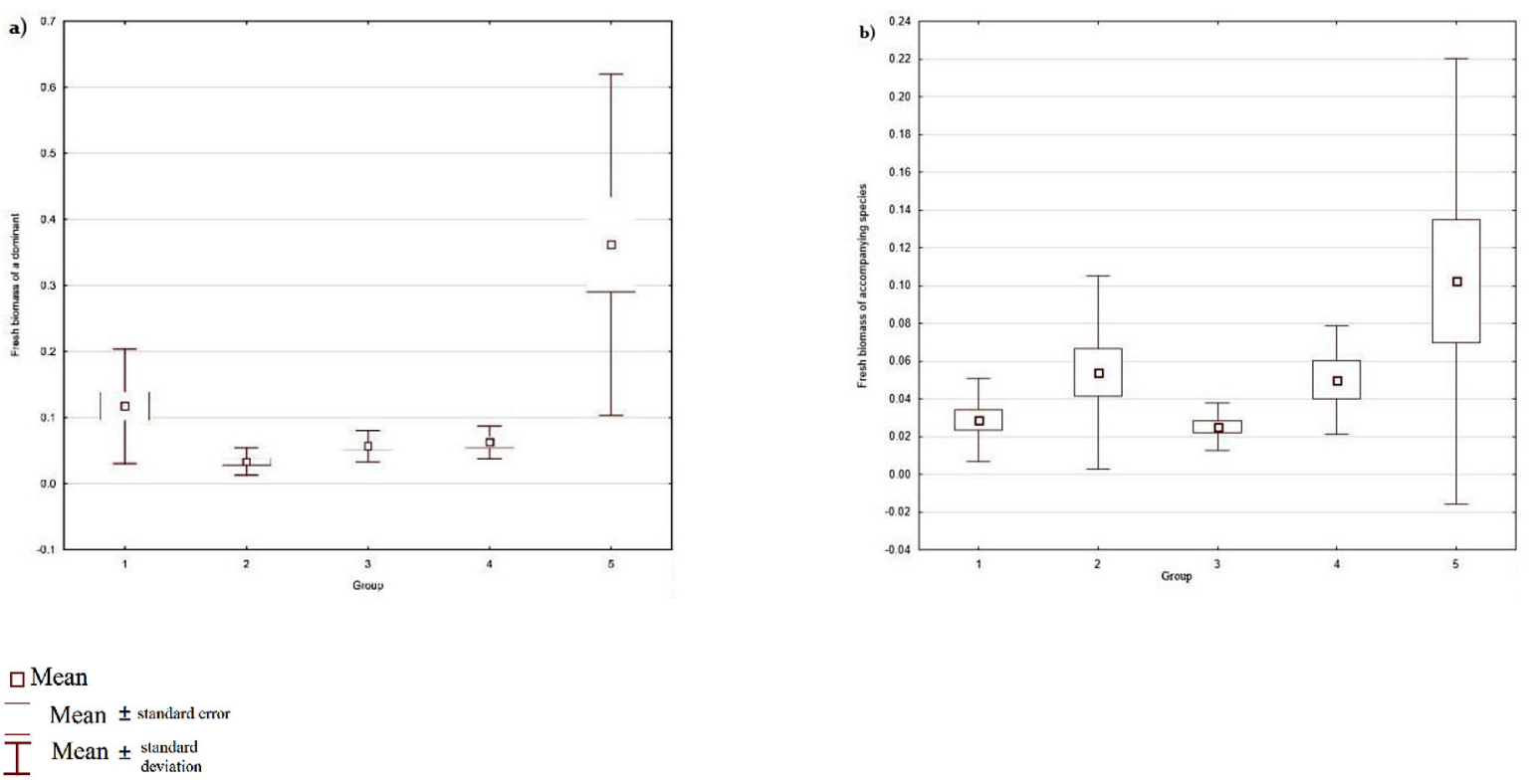

Fig. 4. The comparison of grass communities in reference to: a) fresh biomass of a dominant; b) fresh biomass of accompanying species. Abbreviations :1 - Calamagrostis epigejos com., 2 - Poa compressa com., 3 -Festuca rubra com., 4 - Festuca arundinacea com., 5 - Phragmites australis com.

sition of the Phragmites australis community, in reference to nitrogen, in comparison to other communities. In the floristic composition of the communities with high abundance of Poa compressa, Festuca rubra and $F$. arundinacea the species that prefer a lower nitrogen concentration in the soil, in comparison to Phragmites australis com., were found. In the floristic composition of the patches with Poa compressa, more species that prefer alkaline soils, in comparison to the phytocoenoses dominated by Festuca rubra, Festuca arundinacea or Phragmites australis, were observed.

\section{DISCUSSION}

The data on the biology and habitat preferences of species that spontaneously colonize spoil heaps and form plant communities can be used in the planning reclamation works on various post-industrial wastelands. These species are better adapted to harsh habitat conditions. The use of floristic criteria allowed to distinguish 5 plant types of communities. In the plant communities that develop in post-mining waste dumps, very often one of the most abundant species gives them specific physiognomy and has influence on the diversity of communities. In the case of our 

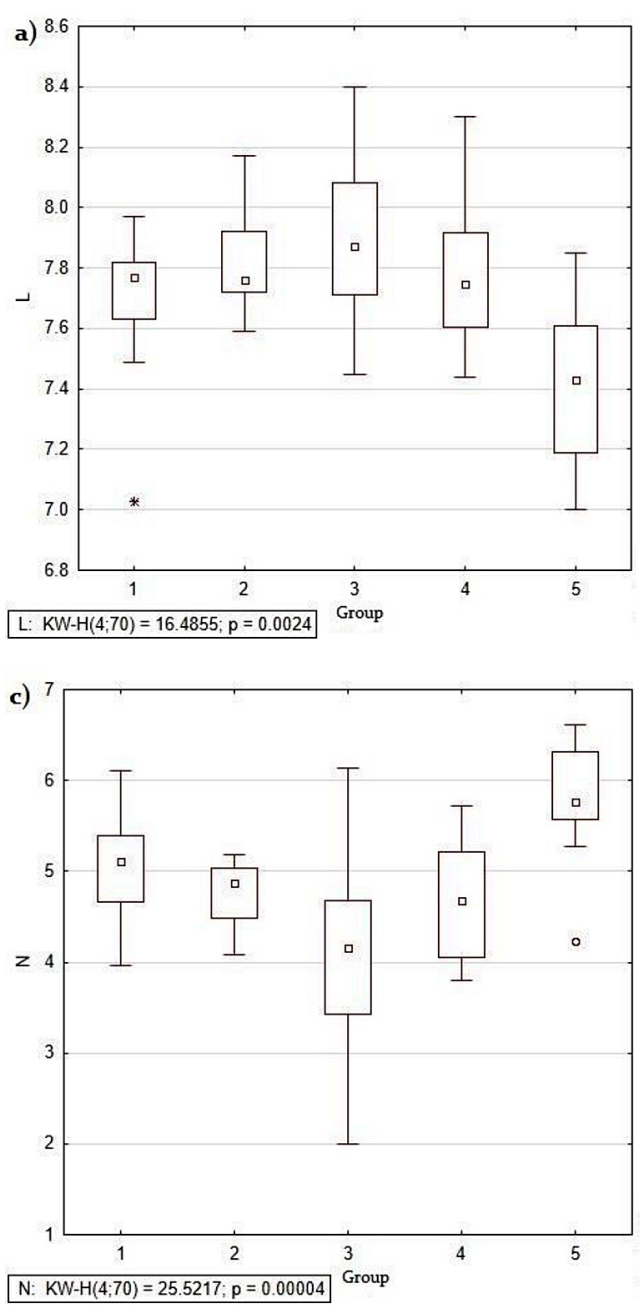
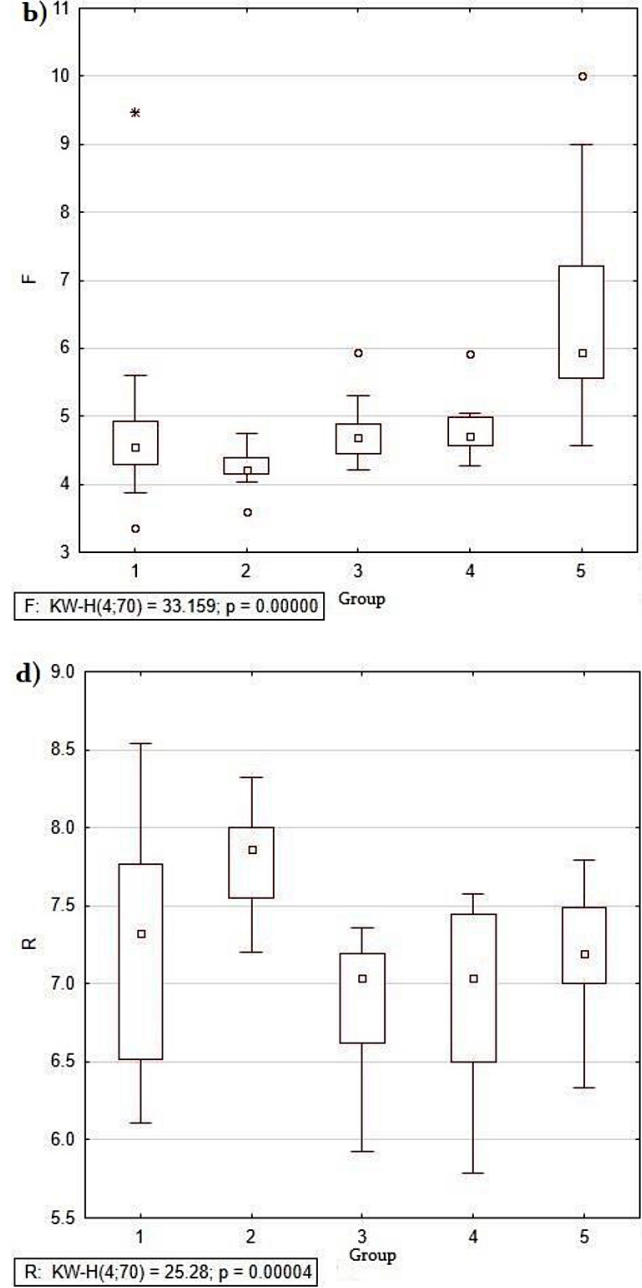

\section{- Median \\ $\square 25 \%-75 \%$ \\ I Min-Max \\ - Outliers \\ * Extreme outliers}

Fig. 5. Comparison of distinguished plant communities in terms of habitat preferences of their species with respect to: a) - light (L): 6 to 7 to full light (8 to 9), b) - moisture (F): fresh substrates (4-5) to wet substrates (8-9), c) - nitrogen $(\mathrm{N})$ content: from poor (2-3) to the rich (6-7); d) - soil reaction (R): moderately acidic substrates (4-5) to slightly acidic and alkaline substrates (6-7);

1 - Calamagrostis epigejos com., 2 - Poa compressa com., 3 - Festuca rubra com., 4 - Festuca arundinacea com., 5 - Phragmites australis com.

research, such grass species as Calamagrostis epigejos, Poa compressa, Festuca rubra, Festuca arundinacea, Phragmites australis played the role of dominants.

The mosaic of habitats in post-industrial areas generates a different course of vegetation succession [Woźniak, 2010; Woźniak and Cohn 2007; Kompała-Bąba, 2013; Woźniak et al., 2015] and has an influence on the presence of species with different life strategies, representing different ecological groups, and having diversified habitat preferences in terms of light, moisture, nitrogen content or soil reaction. Therefore, they can use the limited resources occurring on wastes, e.g. water, nutrients, from coal dumps, in different ways and utilize a given dimension of ecological niches. The grass-dominated communities presented in this paper differ in the quantitative and qualitative share of species representing different ecological groups, e.g. meadow species predominated in the patches of the communities of Festuca rubra or $F$. arundinacea, grass species in the patches of Poa compressa, perennial ruderal species in of Calamagrostis epigejos patches. The species occurring in the floristic composition of the examined plant communities prefer the sites 
ranging from sunny (Festuca rubra, F. arundinacea) to shaded (Phragmites australis), from dry (Poa compressa, Calamagrostis epigejos) to wet (Phragmites australis), from nitrogen-poor (Poa compressa, Festuca rubra, F. arundinacea) to rich (Phragmites australis), from acidic to alkaline (Poa compressa) substrates. Our results confirmed the results obtained on similar post-industrial sites by Rostański, [2000; 2006]. Rostański [2000] studying the flora of post-industrial areas, found the considerable diversity of flora in terms of the habitat conditions [moisture and soil fertility, the reaction of the substrate], and the species recorded are often characterized by a wide range of most ecological factors. However, in the flora of postindustrial areas [hard coal mining heaps, sodium heaps], a clear share of mesophilous and moisturedemanding species [Cohn et al. 2001] and of aquatic and rush habitat species [Rostański, 2006] was often observed. According to Rostański [2006] the share of these ecological group of species can be linked to the heterogeneity of the landfilled waste, which is related to the quantity of mineral colloids in the substratum that occur on heaps.

\section{CONCLUSIONS}

1. On the basis of the floristic criterion, 5 plant communities dominated by different grass species were distinguished. One species often played a dominant role in them, and cover 20$100 \%$ of a patch.

2. The communities differ in reference to the species preferences to light, moisture, soil fertility and reaction, which is reflected in the wide variety of microhabitats in the area.

3. It was shown that the increase in the abundance of certain grass species, e.g. Calamagrostis epigejos, Festuca rubra, Festuca arundinacea, Phragmites australis, has a significant negative impact on the species richness, species diversity and the uniformity of distribution of species in the plant communities.

4. Preliminary analyses revealed that on postmining waste, the biomass production of the dominant species is negatively correlated with biodiversity.

5. The knowledge about biology and ecology of grass species, as well as on the assembly rules may be used in the reclamation of degraded areas.

\section{Acknowledgements}

This study was a part of InfoRevita project TANGO ID: 268600 financed by NCN. We wanted to thank the students participating in the project InfoRevita for their excellent technical support.

\section{REFERENCES}

1. Błońska A., Chmura D., Molenda T. 2013. The ecological conditions of the occurrence of Drosera rotundifolia in man-made habitats. International Multidisciplinary Scientific GeoConference Surveying Geology and Mining Ecology Management, SGEM, 1, 947-954.

2. Bradshaw AD. 2000. The use of natural processes in reclamation - advantages and difficulties. Lands. Urban Plan 51, 89-100.

3. Cohn V. J., Rostański A., Tokarska-Guzik B., Trueman I.C., Woźniak G. 2001. The flora and vegetation of an old solvay process tip in Jaworzno (Upper Silesia, Poland). Acta Societatis Botanicorum Poloniae 70(1), 47-60.

4. Diaz S., Lavorel S., de Bello F. et al. 2007. Incorporating plant functional diversity effects in ecosystem service assessments. Proceedings of the National Academy of Sciences of the United States of America 104, 20684-20689.

5. Chmura D., Molenda T., Błońska A., Woźniak G. 2011. Sites of leachate inflows on coalmine heaps as refuges of rare mountainous species. Polish Journal of Environmental Studies, 20(3), 551-557.

6. Chmura D., Błońska A., Molenda T. 2013. Hydrographic properties and vegetation differentiation in selected anthropogenic wetlands. International Multidisciplinary Scientific GeoConference Surveying Geology and Mining Ecology Management, SGEM, 1, 555-562.

7. Ellenberg H, Weber HE, Düll R, Wirth V, Werner W, Paulissen D. 1992. Zeigerwerte von Pflanzen in Mitteleuropa. Scripta Geobotanica 18. Göttingen.

8. Frey L. 2000. Trawy niezwyciężone [wybrane zagadnienia $\mathrm{z}$ historii, taksonomii i biologii (Poaceae). Łąkarstwo w Polsce 3, 9-20.

9. Frieswyk C.B., Johnston C.A., Zedler J.B. 2007. Identifying and characterizing dominant plants as an indicator of community condition. Journal of Great Lakes Research 33 (3), 125-135.

10. Gajos S., Dygdała W., Mieszczak U., Szwajda S. 2010. The activities of Katowicki Holding Węglowy S.A. to limit the negative environmental effects of mining. Górnictwo i Geologia 5(1), 2157 (in Polish). 
11. Grime J.P. 1998. Benefits of plant diversity to ecosystems: immediate, filter and founder effects. Journal of Ecology 86, 902-910.

12. Kondracki J. 2002. Regional Geography of Poland. PWN, Warsaw (in Polish).

13. Kompała A., Woźniak G. 2001. The role of grasses in chosen anthropogenic plant communities in the Upper Silesia Industrial District. In: L. Frey (eds.) Studies on grasses in Poland, 329-351.

14. Kompała-Bąba A., Bąba W. 2013. The spontaneous succession in a sand-pit - the role of life history traits and species habitat preferences. Polish Journal of Ecology 61(1), 13-22.

15. Kozłowski S., Goliński P., Golińska B. 2000. No-fodder function of grasses. Łąkarstwo w Polsce 3, 79-94 (in Polish).

16. Maciak F. 1999. The protection and reclamation of the environment. Wyd. II. Wyd. SGGW, Warszawa (in Polish)

17. Markowicz A., Woźniak G., Borymski S., Piotrowska-Seget Z., Chmura D. 2015. Links in the functional diversity between soil microorganisms and plant communities during natural succession in coal mine spoil heaps. Ecological Research, 30(6), 1005-1014.

18. Matuszkiewicz W. 2001. A guide for the identification of Polish plant communities. Wydawnictwo Naukowe PWN, Warszawa (in Polish).

19. Molenda T., Błońska A., Chmura D. 2013. Hydrochemical diversity of anthropogenic wetlands developed in disused sandpits. International Multidisciplinary Scientific GeoConference Surveying Geology and Mining Ecology Management, SGEM 1, 547-553.

20. Mirek Z., Piękoś-Mirkowa H., Zając A., Zając M. 2002. Flowering plants and pteridophytes of Poland. A Checklist. W. Szafer Institute of Botany, Polish Academy of Sciences, Kraków.

21. Mitek A. 2015. A big mountain on the edge of Zabrze. Runmageddon Silesia will run there. In: pokladykultury.pl, przekop główny aktualności (in Polish).

22. Mokany K., Ash J. \& Roxburgh S. 2008. Functional identity is more important than diversity in influencing ecosystem processes in a temperate native grassland. Journal of Ecology 96, 884-893.

23. Nicia P., Bejger R., Błońska A., Zadrozny P., Gawlik A. 2014. Characteristics of the habitat conditions of ash-alder carr (Fraxinio-Alnetum) in the Błędowskie Swamp. Journal of Food, Agriculture and Environment, 12(2), 1227-1232.

24. Oberdorfer E., Muller T., Korneck D., Lippert W., Markgarf-Dannenberg I., Patzke E., Weber H. E. 1990. Pflanzensoziologische Excursionsflora. 6
Auflage. Ulmer, Stuttgart.

25. Pełka-Gościniak J. 2015. Plans of management of spoil tips of black coal mine "Murcki" in Katowice. Acta Geographica Silesiana, WNoZ UŚ, Sosnowiec, 18: 59-67 (in Polish).

26. Probierz K., Gawor Ł., Jonczy I., Marcisz M. 2017. Valorisation of post-mining waste dumping grounds from the mines of Katowicki Holding Węglowy S.A. Gospodarka Surowcami Mineralnymi - Mineral Resources Management, 33(1), 3550 (in Polish).

27. Rostański A. 2000. Summary of current research on flora of post-industrial areas in Upper Silesia (1989-1999). Acta Biologica Silesiana 35(52), 151-160 (in Polish).

28. Rostański A. 2006. Spontaneous plant cover on colliery spoil heaps in Upper Silesia (Southern Poland). Wydawnictwo Uniwersytetu Śląskiego $\mathrm{Nr}$ 2410. Katowice (in Polish).

29. Rostański A., Woźniak G. 2007. Grasses (Poaceae) on post-industrial waste sites in course of spontaneous succession. Fragm. Flor. Geobot. Polonica Suppl. 9, 31-42 (in Polish)

30. Ryś K., Radecka K., Kompała-Bąba A. 2016. The plant communities dominated by grasses recorded on wastelands connected with processing of lead and zinc ores. Łąkarstwo w Polsce 19, 229-244.

31. Simberloff D. and B. Von Holle. 1999. Positive interactions of non-indigenous species: invasional melt-down. Biol. Invasions 1, 21-32.

32. StatSoft, INC. 2011. STATISTICA (data analysis software system), version 10.0. www.statsoft.com.

33. Tichý L. 2002. JUICE, software for vegetation classification. J. Veg. Sci. 13, 451 -453.

34. Tichý L., Holt J. 2006. JUICE. A program for management, analysis and classification of ecological data. Vegetation Science Group, Masaryk University Brno, Czech Republic.

35. Woźniak G., Cohn, E.V.J. 2007. Monitoring of spontaneous vegetation dynamics on post coal mining waste sites in Upper Silesia, Poland. Geotechnical and Environmental Aspects of Waste Disposal Sites - Proceedings of Green4 International Symposium on Geotechnics Related to the Environment pp. 289-294.

36. Woźniak G. 2010. Diversity of vegetation on coalmine heaps of the Upper Silesia (Poland). W. Szafer Institute of Botany. Polish Academy of Science, Kraków, p 310 (in Polish)

37. Woźniak G., Markowicz, A., Borymski, S., Piotrowska-Seget, Z. , Chmura, D., Besenyei, L. 2015. The relationship between successional vascular plant assemblages and associated microbial communities on coal mine spoil heaps. Community Ecology, 16(1), 23-32. 